\title{
Managerial Overconfidence and Discretion: Do Managerial Hubris Affect The Dividend Policy In Pakistan?
}

\author{
Rasheed $\mathrm{R}^{1}$, Sadaqat $\mathrm{S}^{2}$, Chughtai $\mathrm{S}^{3}$ \\ ${ }^{1,2,3}$ International Islamic University Islamabad (IIUI), Islamabad, Pakistan
}

\begin{abstract}
This research is conducted to investigate the link between managerial overconfidence and dividend payout in an emerging market of underdeveloped country Pakistan. Managerial discretion levels, individual, organization and environmental are also proposed and verified if moderating the relationship between the respective independent and dependent variable. 62 companies listed on Pakistan stock exchange based on trading volume over the period 2009 - 2011 are selected as sample for empirical substantiation. Regression results have shown that unlike western countries Pakistani managers are not overconfident while formulating dividend policy evident by weak positive relationship between managerial overconfidence and dividend payout. Out of the moderating variable 3 levels only individual and organizational level are found to strengthen the negative relationship between the dividend payout and managerial overconfidence and complies with literature comprehension. No evidence is found that signifies the proposed moderating role of environmental level.
\end{abstract}

Keywords: Managerial overconfidence, dividend payout, managerial discretion, Managers of Pakistan

\section{Introduction}

It has been four centuries since the firms are distributing the dividends, but the complete comprehension of the dividend policy factors and their interaction is still a job. Based on Miller and Modgliani's [7] proposition of dividend irrelevance in 1961, Black [1] invented the term "dividends puzzle" to help understand the intricate phenomena of dividend payment: "The harder we look at the dividend picture, the more it seems like a puzzle, with pieces that just don't fit together." Brealey\& Myers [2] reported 'dividends' as one of the ten key unsolved problems in finance. The riddle of dividend puzzle gyrates around finding out why dividends are paid by the companies and the reason of attention paid by the investors to the dividends. According to Brealey\& Myers [3], it is a trade-off between retaining earnings on one hand and paying out cash and issuing new shares on the other.

Human beings fall prey to irrationality while making decisions and now termed as "bounded-rational" by the researchers $[4,5]$.This bounded rationality in managers gives birth to the cognitive biases that subject them to errors. Much empirical evidence is available to illustrate the effects of behavioral biases endured by the managers. Decisions that are taken under the influence of such behavioral biases mislead a manager resulting in potentially poor results in the favor of corporation and its stakeholders.

One of the most debatable biases in the area of behavioral finance is overconfidence found in the executive class managers. This topic is gaining much attention in the area of corporate finance where recent researches support the effects of managerial overconfidence and discretion on firm's key financial decisions. Managerial content to exercise his discretion always comes into play while making dividend payment policy. Studies have been conducted in strong financial markets but the underdeveloped or emerging markets like that of Pakistan are still under explored in this regard.

This research is to investigate the presence of overconfidence in Pakistani executives who are involved in formulating strategies and policies like dividend distribution or retention. Secondly, our research also calls to answer the moderating effect of managerial discretion on dividend payout and overconfidence. Also this research suggest recommendations to overcome the hubris biases exhibit by managers in Pakistan that leads to erroneous and contradictory decisions to that of investor preference.

\section{Literature Review}

Dividend payments are regarded as an efficient method of distributing cash to shareholders and an most advantageous way to minimize the transaction cost associated with shareholders' funds management, but it has been observed that increasing number of firms are switching over to other modes of income distribution such as stock repurchases. On the other hand, dividends are also thought to be an inept way of distributing cash to respective shareholders. As dividends are subject to double taxation, stock repurchases are thought to be a better method in this regard [6].

To pay dividend to shareholders or to further invest the earnings for growth is one of the three key financial decisions that the senior managers of public companies have to consider all the time [7]. Over the years, multiple theories have tried to explain the dividends phenomenon, but no conclusive agreement has been 
found between them. Researches in the area of Finance have come up with three principal paradigms that help describe the dividend puzzle [8]. Miller \& Modigliani [7] argued the assumptions of perfect markets, rational behavior and perfect certainty, and found that the relationship between the value of the company and the current dividend policy is irrelevant. Under perfect capital markets, dividends are not relevant to the firm's value is generally held to be valid [7]. The conditions of perfect capital market are much strict in a sense and do not comply with the real practical markets. Taxes along with asymmetric information, agency and transaction costs are some of the cipher of market imperfections, supporting the proposition that dividend policy is relevant to firm value. The existence of market imperfections has laid basis of number of dividend theories such as signaling theory, tax clientele theory, agency theory, residual theory and stability theory of dividends [9]. Miller and Modigliani have developed a framework for the consequent research on dividend payout policy.

Considerable research has been done to identify the determinants of corporate dividend policy. One of the pronounce determinant is 'Agency' related rationale followed by the idea that monitoring of the firm management is helpful in curbing agency conflict and assuring that managers are not abusing their positions [10]. Persistent distribution of cash out of the income stream discipline managers and results in reduced agency cost [11]. Fama and Jensen [12] argue that agency problems can be resolved by the payment of large dividend to shareholders. It is assumed that when a firm increases its dividend payment, it has to raise additional finance from the capital market to proceed with intended investment. This leads to an involvement of both the potential investors of the firm and management in monitoring, thus reducing the agency issue. Many of the theories view agents as rational and dividends either serve as an efficient way to resolve agency problems or as a signaling device to mitigate information asymmetry problems. Among the conflicts of interest between various corporate claimholders, information asymmetry is the most evident. It holds that insiders such as managers have more information about the firm's cash flow than the providers of the funds [8]. Signaling theory suggests that managers use dividends to signal their private information to investors [13,14 and 15].

Dividend announcement gives a signal to the shareholders. There is always an obvious difference of information between the managers and the shareholders, where managers have more complete information than shareholders. Shareholders will take an increase in dividend payments by the company, as a signal that management has a high cashflow forecast future [1]. They hold an opposite view regarding the decline in dividend payments and interpret it as a reducing cashflow in the future. If a manager believes that his firm would be able to maintain the consistency in cashflows in the future, then he will increase the dividend payments [16]. The supporting evidence for Lintner's research was provided by Fama and Babiak [17] in 1968. Dividends signal a firm's future prospects and are paid even if a firm has laudable investment prospects [18, 19].

Signaling theory accentuates the role of dividend policy under asymmetric information. It suggests that the company's dividend announcement is the most valuable source that conveys information about management's estimation of its future financial prospects. Reducing the information asymmetry between managers and outside investors, dividend announcements are used as a tool to assess a firm's future stock price. This elucidation illustrates that dividend changes should lead, rather than lag, earnings changes [20].

Tax differential between capital gains and dividends also led to the development of an optimal dividend policy [21, 22]]. It has been observed that investors favor preservation of funds rather than the imbursement of dividend because of tax- related reasons. This help illustrates that companies must keep dividend low in order to keep their prices maximum. Higher the dividend payout ratio, lower the firm stock price [23]. However, other researchers have reported that the value of a firm is independent of its dividend policy [24, 25]. High tax burden on individuals juxtapose that the firms should minimize dividend payments [6]. The tax clientele theory suggests that investors select portfolios in accordance with their marginal tax rates. Amendment in the tax position of shareholders is caused by the change in dividends and encourages investor trading to rebalance their portfolios [7].

Other studies have also found sustaining evidence among institutional investors for dividend clientele. Higher dividends draw institutional investors since they are taxed less than retail investors [26]. Dhaliwal et.al [27] and Seida [28] find empirical evidence that supports the existence of tax-based clientele for dividends.

\section{Link Between Dividend Payout And Firm Characteristic}

Even after decades of study, the factors influencing the dividend policy and the way in which these factors interrelate have not been completely apprehended. Three important factors that are thought to be affecting the dividend policy are growth opportunities, cash flow, and firm size i.e. a measure of asymmetric information [29, 30]. Numerous studies have identified negative relationships between the growth opportunities and dividend, while a positive relationship between the dividend payout and cash flows [31]. Previous studies have detected a large number of firm-specific variables as the determinants of dividend payouts, such as firm size, market-to-book ratio, leverage, R\&D spending, capital expenditures, and CEO tenure [32]. 
Other literature also proposed a relationship between investment opportunities and dividend policy. Studies have revealed that an investment opportunity set determines firm's dividend payout policy. It is found that low dividend policy is pursued by firms having appreciable investment opportunity set, since dividends and investment represent opposing potential uses of a firm's cash resources [29, 33]. Firms that have a potential investment opportunity set generally reduce dividend payout [34]. If a firm has high investment possibilities available, they would tend to pursue very low dividend distribution to preserve funds for future investments.

Much evidence has been found to support the link between dividends and idiosyncratic risk. Venkatesh [35] observed a decline in idiosyncratic risk and the informational content of earnings following dividend initiation. An observation that the dividend-paying firms have lower idiosyncratic volatility has previously been reported [36]. Only a firm that is sure about its future cashflow stream would feel comfortable in paying dividends [37, 38]. Hoberg and Prabhala [39] determine that the disappearance of dividends [Fama and French, 30] is associated with an increase in idiosyncratic risk.

A model of dividend payout has been proposed which is based on principle-agent paradigm. A manager or an agent has his own potential to identify and grab positive NPV projects. This idea has stem from the asymmetric information context. Based on an economic instinct, the principles prefer agents having access to the projects having positive NPV; and if these projects are unavailable, principles prefer agents to distribute cash dividend [40].

Managers with the varying productivity are offered different compensations by the shareholders. Managers with less access to positive NPV projects i.e. low productivity are forced to distribute cash dividends by their shareholders. In contrast, managers with high productivity are offered incentives to invest free cash in prolific business ventures. Hence, an inverse relationship has been found between the dividend payout and managerial productivity, with a positive relationship between managerial compensation and productivity. Higher the compensation, higher would be the managerial productivity followed by a low dividend payout. At times, in order to show high level of productivity to augment compensations from shareholders, managers invest in negative NPV projects. This attitude causes managers to undertake poor investment prospects, leading to overinvestment problems [41]. To mitigate this approach of managers, it has been proposed that the excess cash should be distributed as dividends to the shareholders [42, 43].

Another approach discussing dividend payout by a firm is the life cycle theory. According to this theory, firms pay dividend only at the maturing stage of life. As firms mature, they begin to distribute dividends, since they have if they have few investment opportunities but stable cashflows and high profitability [6]. On the other hand, young firms with abundant investment opportunities but scarce resources accentuate more on retaining free cashflow [44].

\section{Managerial Overconfidence And Financial Decisions}

For human beings, rationality can be defined as a mental ability or an innate quality to differentiate between right and wrong at a certain point in time. It is how a person confirms his believes and actions with the reasons of respective beliefs and actions. When a person is highly objective, logical and mechanical, he is termed as "rational". If his personal emotions, moral norms and codes come into play, his so-called rationality is questioned and takes the form of irrationality. Rationality is also considered as an "optimization". It means that if the sophisticated information content is available, then the decision making will be a process of finding a rational optimal choice.

It is a human tendency to propagate his being as rational, but the real life situations illuminate that grey area on board where he is neither rational nor irrational. This kind of human behavior is illustrated in some models of social sciences, assuming human as a reasonably estimated rational entity. The concept of "Bounded rationality" has emerged from the very same thought. While making decisions, people fall into the pit of bounded rationality, reflecting their cognitive biases in the decision [45].The limitation of information content drives away a manager from the rationality. Other constraints such as time and a lack of analytical skills also detract a manager from making the best possible decision rather than the optimal one.

Bounded rationality allows an individual to apply their sagacity according to their preferences after simplifying the choices available. This miscalibration of probabilities to reach the desired outcome brings into play the cognitive bias of overconfidence. The behavioral pattern of overconfidence and its effects in relation with financial decision making have already been studied in much depth. However, much room is available in the area of senior managers' overconfidence and its impact on dividend policy making.

Overconfidence is an overestimation of one's own capabilities, especially when a task involves a partially stochastic outcome [46, 47, 48 and 49]. Based on one of the most prominently established fact from the literature of social psychology, individuals are inclined to overestimate their judgment potential relative to the average when it comes to appraisal of their skills [50, 46 and 51]. The human expectancy to produce success leads an individual to attribute good outcomes to their own actions, but bad outcomes to bad luck [52]. Overconfidence or hubris embolden decision makers to overemphasize their problem solving capacities [53], 
while underestimating the resource limitation [54] and uncertainties faced by their firms [55, 56 and 57]. Executives appear to be particularly prone to display overconfidence [50,57 and 58].It is a human characteristic found in the certain types of people of general population, being prevalent in executives [60]. CEOs suffering from the dilemma of inflated egos tend to take risks that are not in the best interests of shareholders [61, 62]. This hubristic behavior of a manager not only damages firm's fundamental interest but also ruins his own career [63].

While taking investment and financial decisions, overconfident managers normally suffer from "hubris" i.e. the tendency to over invest OR underinvest [50, 64]. In case of sufficient internal cashflow, managers believe that market has done an undervaluation of their firm that would cause the interest and dividends yields to get too high. Heavy reliance on internal financing discourages a manager to grab a potential investment opportunity, which demands external financing. This stigma causes the manager to prefer the internal funds over debt as compared to other rational decision makers in their peer group. However, the counter argument proves that higher the level of overconfidence in managers, more they go for debt or short term debt [65, 66 and 67].

Managerial overconfidence also results in under investment, when internal cashflow is insufficient. They overestimate the future performance of their enterprise, while expecting a positive stream of cashflows to continue in the future. This wishful thinking abstain them from investing in positive NPV projects, creating an underinvestment scenario in the firm.

How overconfident CEO's beliefs impact dividend policy is a gap that is yet to be filled - both conceptually and empirically. Highly optimistic managers are less likely to pay dividends, put too high a price on their future cash prospects [68]. Excessive internal cashflow abnegates a manager's dividend paying behavior, encouraging them to fund their projects internally. They also act aggressively while implementing corporate policies, if they are confident about their estimations. However, no evidence of less dividend payout by overconfident CFOs has been observed [69]. The valuation yardstick hypothesis and the catering hypothesis discuss the alternative natures of firms' paying dividends. According to the valuation yardstick, firms pay dividends when believed to be undervalued by the investors and alternatively stop to pay in case of overvaluation. On the contrary, the catering hypothesis argues that the firms pay dividends when they are appreciated by the investors and exclude distributing dividends, when they are undervalued in the market [6]. Some other studies have revealed the psyche of managers' to distribute the cash when they are positive about the cashflows from current investments, while lowering the distribution of cash dividends, if they perceive high future investment need. Also, in case of high growth firms, the reduction in dividend payout ratio by the overconfident CEOs is observed to be smaller as compared to the small growth firms. Stock price respond very vaguely to the dividend announcements of the firms that are managed by the overconfident CEOs. However, the existing hypothesis drawn from the previous literature does not confirm the relationship between managerial overconfidence and dividend payout. One school of thought suggests that the reputable CEOs are seldom afraid of the fact that the risky investments will ruin their reputation, if it proved to be a failure. This anxiousness allows them to pay more dividends from the free cash flows. The opposing idea supports the notion that the overconfident CEO will pay fewer dividends assuming that their investment will be auspicious which formulate their belief of holding on to the investment [70].

Manager or a CEO as a leader of a firm can make or break a company [71]. Number of streams has studied the relationship between managerial overconfidence and payout policy, but none proved to be the authority. Overconfident managers are generally expected to have lower propensity to pay dividend, as they prejudicially overestimate the NPV of available investment opportunities [72].

\section{Managerial Discretion}

Research suggests that less constraint and more mean ends ambiguity brings in managerial discretion [73]. Great discretion allows top executives to heavily impact the firm's decisions and outcomes [74, 71]. Managerial discretion provides the top management much room for maneuvering to make strategic decisions. The level of discretion exists to the degree that an executive has alternative actions available that are to be chosen by the stakeholders [75]. This helps us comprehend, when and where the executives would have strategic latitude [76]. It is also a sum of stakeholder progressiveness regarding managerial practices and their inability to wedge obnoxious action. Traits like status and behavior of executives in different parts of the world explains the managerial discretion in different parts of the world.

One factor that reduces the value of a corporation is the cost associated with managerial discretion. Managers' poor decisions like investing cash in projects below their cost of capital, or wasting free cash ineffectively brings in such costs [77, 78]. Even if a manager is more involved in his personal interests, he would take actions to maximize his own utility of wealth rather than that of stockholders [79]. 
When it comes to dividends, managers are given much more discretion to decide the appropriate level. At times their behavior is not in sync with the interests of the shareholders, leading to imperative distortion. Sometime managers are under the pressure of shareholders to pour out cash [44], while some are contented with the ungenerous dividend approach [7,80]. To avoid consequences caused by cutting dividend, managers prefer laying off employees, forgoing positive NPV projects and focus more on credits and assets selling [81].The extent of managerial discretion originates from the three levels: Individual, organizational and the environment. These three levels have been studied by the researchers in their own perspectives. All of these levels are explained in our theoretical development.

\section{Hypothesis Drawn From Literature}

Even after the development of multiple theories on the phenomena of dividend distribution, the puzzle is yet to be solved. There is still no clear answer that can remove the ambiguities regarding why do firms distribute dividend to their shareholders? There are two basic assumptions that explain all the theories related to dividend distribution. One approach talks about the rationality, while the other one contradicts it, bringing into the concept of irrational approach of firms. According to the rational approach, managers pay dividend to solve the issue of information asymmetry and to reduce the agency cost [82].

This paper attempts to explain that the managers behave irrationally while taking dividend decisions. Here we explore one branch of managerial bias i.e. overconfidence and its relationship with the dividend payout. Limited literature is available that explains managerial discretion in emerging markets. This is the first time that we test the relationship between managerial overconfidence and dividend payout in the underdeveloped market of Pakistan.

First approach supporting irrationality suggests that managerial overconfidence lead to either overinvestment or underinvestment, depending on the availability of internal cashflow. Managers assume that the market has undervalued their firm which has increased its cost of external financing. If the internal cashflow is sufficient, managers will pick a number of projects irrespective of its positive or negative NPV. Contrarily, an underinvestment will take place, if the internal cashflow is scarce. Overconfident managers tend to reduce the cash dividend if they perceive high investment need, while increasing the dividend payout if they are positive about the cashflows from the current investments. A converse view advocates that the overconfident managers are more likely to pay dividends as they more often go for short term debt and also believe that less dividend payout will affect their reputation in turn reducing their compensations. In Pakistan, dividend payout in the behavioral context has yet to be explored, whereas previous researches have focused on the institutional factors like last year dividend, firm size, net profit earned and cashflow implications of firms' other key decisions. Pakistan is unlike developing countries in terms of its level of corporate governance and future outlook. Most of the business ventures of Pakistan are family owned and also the advanced positions are held by them. These managers exploit the surplus cashflow because of their overconfidence believing that their parental firms have much more opportunities than their peers.

\section{$H_{I}=$ In Pakistan, there is a negative relationship between managerial overconfidence and dividend} distribution.

\section{The Moderating Effect Of Managerial Discretion}

The extent of managerial discretion originates from the three levels: Individual, organizational and the environment [Hambrick and Finkelstein, 75]. These three levels have been studied by the researchers in their own perspectives.

A. Individual: Individuality, as per managerial discretion, has occasionally been described in both structured and unstructured terms. It can be the power consigned to him by the shareholders or the envisioning of alternatives based on his personal characteristics, locus of control and varying degree of creativity [83]. The agent and the principal acts in his respective self-interest that creates conflict between them. These inconsistent behaviors of two entities give rise to agency problems. It has also been observed that the asymmetric information content in relation with the conflict of interest between the manager and an agent escort the agency costs [84, 85 and 86]. To reduce the principal-agent conflict gulf, principal has to move one step further keeping his self-interest aside. On one hand, shareholders uses agents' aptitude and skills in an attempt to get plausible returns on their investment while minimizing the agency problem possibly caused by moral hazard, adverse selection and hold-up [87]. To resolve this conflict, two views which are directly at odd with each other are drawn from the agency theory. One view hypothesize that CEO's dual role can wedge the agency conflict between the principal and the agent. Researchers in Pakistan have confirmed a positive relationship between CEO duality and dividend distribution [88]. Absence of strong vigilant board allows a manager to misuse his powers and make a decision of his own choice i.e. either by retaining the cash or by simply not distributing the cashflows. Opposing view extracted from the literature suggests that plausible monitoring of an agent is possible 
by splitting his positions as a board chair and a CEO. A failed attempt to dissociate the two positions will be followed by an underperformance [89]. Jensen [90] along with some regulatory bodies have come to an agreement that the only prudent way to solve the agency conflict is splitting of agent's two positions.

$\mathrm{H}_{2}=$ In Pakistan, relationship between managerial overconfidence and dividend distribution is strengthened by the $\mathrm{CEO}$ duality.

B. Organizational: In broad literature, organizational level is termed as "financial resources" i.e. size of the firm, but an unprecedented idea of "passive board" i.e. organizational hierarchy, and CEO duality have also been advocated. CEO duality is a situation when the CEO also holds the position of the chairman of the board. The joint positions of CEO and the chairman allow more discretion to that executive to drive the firm in risky directions. Duality drives an executive more towards his personal preferences in an unchecked manner [91, 92]. Size of the company i.e. the size of the resources relates to the executives' discretion to control these resources [93]. Apart from the tangible ones, the intangible resources have much importance for a firm to attain a protractible competitive advantage [94]. Resource-based theorists have contemplated that the rate and direction of a firm's growth is dependent on the firm's portfolio of tangible and intangible assets [95]. Higher organizational growth due to better financial resources permits more discretion to the managers. Organizational hierarchy projects the opposite view from the first i.e. larger the organization, greater would be the difficulty in moving away from their pre-defined trajectory.

$\mathrm{H}_{3}=$ In Pakistan, relationship between managerial overconfidence and dividend distribution is strengthened by the size of financial resources.

C. Environment: Integrated researches have confirmed that the task environment also shapes the managerial discretion. Literature supports that the task environment or environmental uncertainty is made up of three elements (Figure 2)

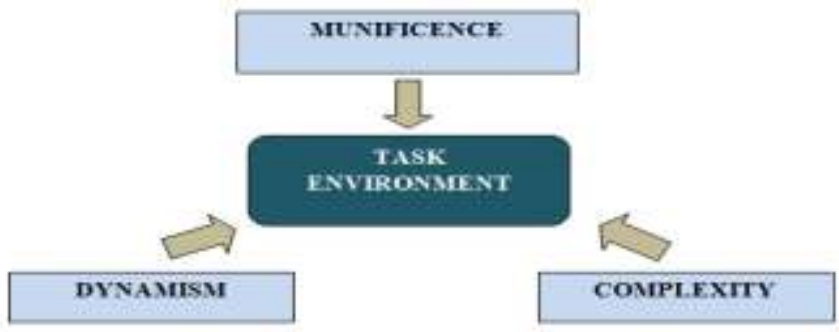

Proposing the definitions for these environmental variables in our own context, Munificence can be defined as the resource availability or organizational slack reducing the environmental uncertainty [96]. Organizational slack can be defined as an excess capacity maintained by an organization consciously as well as unconsciously [97]. Slack exists when the organization holds excessive resources which are not completely utilized ordinarily. Employees are excessively paid than what is required to retain them and also firm charges least possible price to its customers for its product [98]. In more general terms, it is a failure of an organization to work with the full efficiency which is possible, with a resulting surplus of resources above what is strictly necessary.Some executives are given much more leverage in terms of managerial discretion in confirmation with the organizational slack and absence of entrenched culture [99].In the presence of munificent rich environment, organization has abundant resource to support its growth in future. Dynamism, in contrast to munificence augments the environmental uncertainty [100]. In general terms, it can be defined as the volatility or irregularity in the environment. If a firm has diversified portfolio and operating in multiple industries, it will have concentration of inputs or organization density [101]. This concentration of inputs is referred to as complexity and is positively associated with uncertainty in task environment [100], thus allowing much more discretion to the manager.

In Pakistan task uncertainty is at its peak due to political scenario, lack of prudent regulations and sovereign risk. This task uncertainty allows the manager to make decision unorthodoxly while underestimating the indubitable available choices.

$\mathrm{H}_{4}=$ In Pakistan, relationship between managerial overconfidence and dividend distribution is strengthened by the task environment.

\section{State Ownership And Political Appointment}

State ownership, also termed as government ownership or state property is the ownership of an asset or some industry at national or regional level by the government. In contrast to privatization, state ownership is a process of bringing an asset into public ownership. This is termed as "nationalization". State owned enterprises are an important part of the economy where wide interaction between both political and market 
forces coexist. In a state owned environment, managerial discretion is affected to some extent by the political dominance. For example, China is one country where state ownership reduces the level of managerial autonomy [102]. Autonomy to an SOE's management is a function of bargaining power of both the state owner and the firm's management itself [103]. The state owner stems its power from the resource ownership, while the management may gain power from its past performance and political connections.

$H_{5}=$ In Pakistan, there is a weak relationship between managerial overconfidence and dividend distribution due to state ownership.

Where there is state ownership, managers are appointed by the government. This causes an increased pressure on the management to make a decision that is in confirmation with the philosophy of the state. Appointment of staff in state owned enterprises is a highly political issue. The employees in SOEs that were sacked by the earlier government were restored in year 2010 by the government of Pakistan .This was a sheer display of the regime's own political benefits, as no investigation was conducted to establish report whether those employees are already employed somewhere else or self-employed.

$\mathrm{H}_{6}=$ In Pakistan, there is a weak relationship between managerial overconfidence and dividend distribution due to political appointment.

\section{Theoratical Framework}

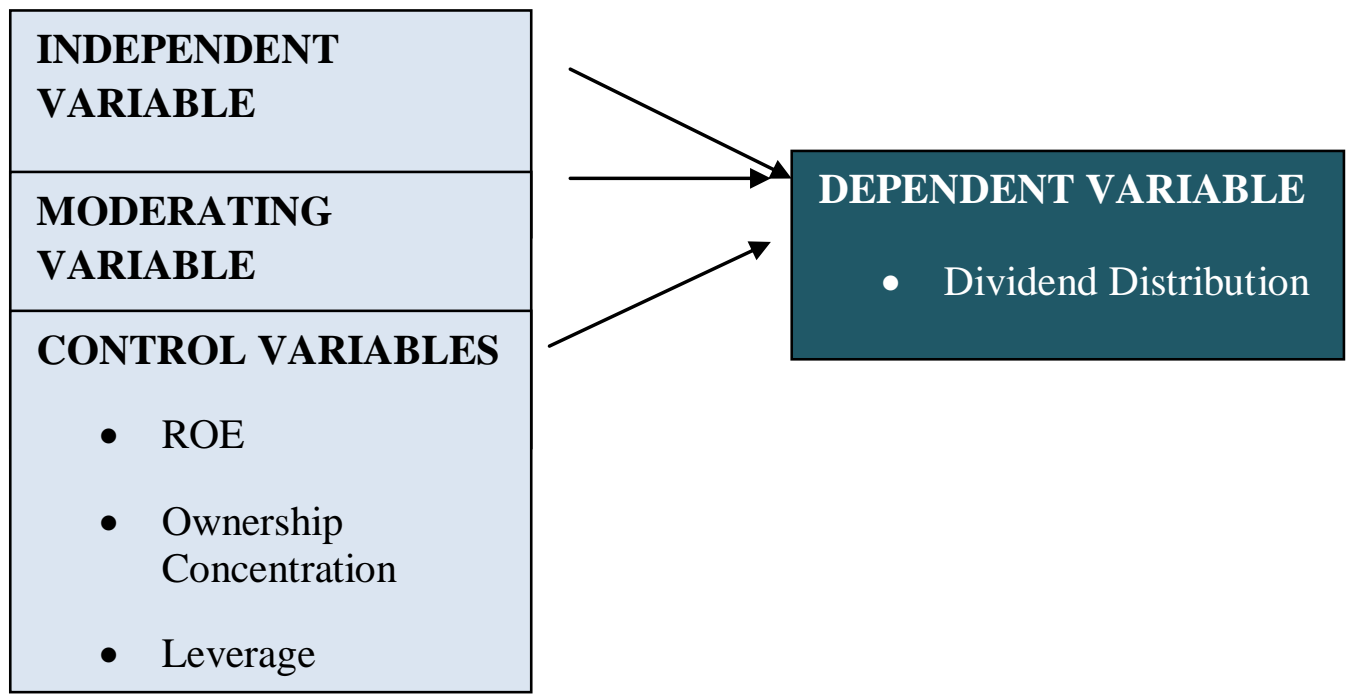

VII. Data Collection

This research has been conducted on the top 100 companies of KSE-100 index of the last day of year 2011. Final sample comprises of required variables for 62 companies over the period $2009-11$, based on the highest to lowest trading volume. All the variables are calculated based on the input from the published financial statements of the respective firms. For statistical interpretation of the designed models, regression analysis has been run on the data set of three years.

\section{DEPENDENT VARIABLE: Dividend}

VIII. Measures

Managers not only distribute income to shareholders in the form of cash dividend but also as bonus shares. Firms also distribute excess cash among the shareholders by buying back the old equity i.e. shares repurchase. However, in Pakistan it's been observed that cash dividend has been the most prudent way of sharing excess income with the shareholders. Also cash is readily available for investing in future prospects, accounting practices regard cash dividend as the real dividend. In this research paper, dependent variable dividend is calculated as dividend per share.

\section{MODERATING VARIABLE:}

CEO DUALITY: CEO holding both the positions of chairman and CEO at the same time is referred as CEO duality. To measure this variable dummies of 1 and 0 have been assigned to ensure the existence of dual position of CEO. 1 is given if CEO is also the chairman of board while 0 is assigned otherwise.

GROWTH: Two measures have been used to calculate growth of the firm: growth in dividend and growth in cash flows over the three years period respectively. Growth in dividend is measured by the dividend growth model and growth in cashflow is measured by free cashflow model. 
FIRM SIZE: Natural log of firm assets of respective year is taken to measure the firm size.

CASHFLOW RESERVE: It is the ratio of total cashflow to the total shares to explain munifence.

STATE OWNERSHIP: Dummy of 1 is assigned to state owned firms while 0 to the private owned firms.

POLITICAL APPOINTMENT: Dummy of 1 is assigned to CEO appointed politically while 0 is assigned otherwise.

OWNERSHIP CONCENTRATION: Dummies of 1 and 0 have been assigned to the institutional investors holding the largest percentage of shares out of all the shareholding bodies. This is based on highest percentage of shares being held by the institution in the shareholding pattern.

RETURN ON EQUITY: This ratio depicts net income earned per unit of equity. It is measured by dividing net income to the total equity.

$\boldsymbol{L E V E R A G E}$ : Leverage is commonly used in the businesses to finance firm assets by the introduction of debt. Leverage is measured by dividing total debt to total assets.

\section{INDEPENDENT VARIABLE:}

OVERCONFIDENCE: Overconfidence is an overestimation of one's own capabilities and the miscalibration of probabilities to reach the desired outcome, [82] have used the similar measure of overconfidence which is the difference between the forecasted and the actual profit in a year.

\section{Models}

In MODEL 1, all of the controlling and moderating variables are added to investigate the relationship between dividend payment and managerial discretion. Following that, MODEL 2 includes the independent variable i.e. overconfidence along with all the controlling and moderating variables. MODEL 3 attempts to explain the interaction of controlling and moderating variables with the overconfidence and its impact on dividend payment.

MODEL $1=\alpha_{0}+\alpha_{1}$ ROE $+\alpha_{2}$ LEVERAGE $+\alpha_{3}$ OWN CON $+\alpha_{4}$ GROWTH $+\alpha_{5}$ FIRM SIZE $+\alpha_{6}$ CEO DUALITY $+\alpha_{7}$ CASHFLOW $+\alpha_{8}$ STATE OWN $+\alpha_{9}$ POLITICAL APP

MODEL $2=\alpha_{0}+\alpha_{1}$ ROE $+\alpha_{2}$ LEVERAGE $+\alpha_{3}$ OWN CON $+\alpha_{4}$ GROWTH $+\alpha_{5}$ FIRM SIZE $+\alpha_{6}$ CEO DUALITY $+\alpha_{7}$ CASHFLOW $+\alpha_{8}$ STATE OWN $+\alpha_{9}$ POLITICAL APP $+\alpha_{10}$ OC

MODEL $3=\alpha_{0}+\alpha_{1}$ ROE $+\alpha_{2}$ LEVERAGE $+\alpha_{3}$ OWN CON $+\alpha_{4}$ GROWTH $+\alpha_{5}$ FIRM SIZE $+\alpha_{6}$ CEO DUALITY $+\alpha_{7}$ CASHFLOW $+\alpha_{8}$ STATE OWN $+\alpha_{9}$ POLITICAL APP $+\alpha_{10}$ OC $+\alpha 11$ GROWTH $*$ OC $+\alpha_{12}$ CEO DUALITY $*$ OC $+\alpha_{13}$ CASHFLOW $*$ OC $+\alpha_{14}$ STATE OWN $*$ OC $+\alpha_{15}$ POLITICAL APP $*$ OC

"FIG. 1"

\section{Results}

\begin{tabular}{|c|c|}
\hline VARIABLES & AVERAGE VALUES \\
\hline Dividend Per Share & 3.631225806 \\
\hline Size of the Firm & 19.98144559 \\
\hline Growth & -1.411492 \\
\hline Overconfidence & -1008907550 \\
\hline Liquidity & 0.554028713 \\
\hline Return On Equity & -0.503800611 \\
\hline Cash Flow Reserve & 21.56759886 \\
\hline
\end{tabular}

FIG 1 explains the average values of dependent variable i.e. dividend per share along with the averages of independent variable i.e. Overconfidence and other moderating variables. For the dependent variable, average computed is 3.63 Rupees per share which is comparatively higher than other emerging markets of countries. In comparison with China where basic research on overconfidence has already been conducted, dividend per share is found to be only 0.105 [82]. Chinese research therefore substantiates the negative relationship between overconfidence and dividend paid per share. In this research, the average of key independent variable managerial overconfidence is highly negative i.e. -1008907550. Overall it can be assumed that Pakistani managers are less overconfident as they forecast future cashflows much less than the actual ones $(\mathrm{OC}=$ Forecasted - Actual). The negative growth in dividend and cashflows is another reason why forecasted cashflows are always less than the actual. 
Managerial Overconfidence and Discretion: Do Managerial Hubris Affect The Dividend Policy In

"FIG. 2"

\begin{tabular}{|c|c|c|c|c|c|c|c|c|c|}
\hline Variables & \multicolumn{3}{|c|}{ Model 1} & \multicolumn{3}{|c|}{ Model 2} & \multicolumn{3}{|c|}{ Model 3} \\
\hline \multirow{3}{*}{$\begin{array}{l}\text { Liquidity } \\
\text { ROE }\end{array}$} & intercept & $\begin{array}{l}\mathrm{P} \\
\text { value }\end{array}$ & $\begin{array}{l}\mathrm{T} \\
\text { value }\end{array}$ & intercept & $\begin{array}{l}\mathrm{P} \\
\text { value }\end{array}$ & $\begin{array}{l}\mathrm{T} \\
\text { value }\end{array}$ & intercept & $\begin{array}{c}\mathrm{P} \\
\text { value }\end{array}$ & $\begin{array}{c}\mathrm{T} \\
\text { value }\end{array}$ \\
\hline & -3.327 & 0.079 & -1.76 & -3.30 & 0.085 & -1.73 & -3.157 & 0.1049 & -1.63 \\
\hline & 0.008 & 0.832 & 0.211 & 0.085 & 0.830 & 0.214 & 0.009 & 0.833 & 0.210 \\
\hline $\mathrm{CF}$ & -0.0005 & 0.818 & -0.23 & -0.0005 & 0.821 & -0.226 & -0.006 & 0.810 & -0.24 \\
\hline Firm Size & -0.763 & 0.0001 & $\begin{array}{c}- \\
3.799\end{array}$ & -0.755 & 0.0004 & -3.580 & -0.818 & 0.0002 & -3.73 \\
\hline Political & 0.233 & 0.949 & 0.063 & 0.540 & 0.903 & 0.121 & 5.19 & 0.769 & 0.293 \\
\hline State & 0.798 & 0.855 & 0.182 & 0.456 & 0.930 & 0.087 & -4.20 & 0.814 & -0.235 \\
\hline Duality & -5.615 & 0.0034 & $\begin{array}{c}- \\
2.967\end{array}$ & -5.607 & 0.0035 & -2.95 & -6.532 & 0.0016 & -3.192 \\
\hline OwnCon & -0.261 & 0.85 & $\begin{array}{c}- \\
0.189\end{array}$ & -0.258 & 0.85 & -0.186 & -0.464 & 0.744 & -0.326 \\
\hline Growth & 0.016 & 0.837 & 0.205 & 0.016 & 0.838 & 0.203 & 0.006 & 0.936 & 0.079 \\
\hline $\mathrm{OC}$ & & & & $4.04 \mathrm{E}^{-11}$ & 0.902 & 0.1229 & $6.6 \mathrm{E}^{-11}$ & 0.8612 & 0.175 \\
\hline OC*Duality & & & & & & & $-1.9 \mathrm{E}^{-9}$ & 0.208 & -1.263 \\
\hline $\mathrm{OC} * \mathrm{CF}$ & & & & & & & $-3.4 \mathrm{E}^{-12}$ & 0.824 & -0.22 \\
\hline OC*Growth & & & & & & & $-9.3 \mathrm{E}^{-12}$ & 0.929 & -0.089 \\
\hline OC* State & & & & & & & $-1.01 \mathrm{E}^{-9}$ & 0.919 & -0.101 \\
\hline OC*Political & & & & & & & $4.3 \mathrm{E}^{-10}$ & 0.819 & 0.2287 \\
\hline Constant & & 21.69 & & & 21.55 & & & 22.87 & \\
\hline F change & & 0.012 & & & 0.021 & & & 0.095 & \\
\hline $\mathrm{R}^{2}$ & & 0.1104 & & & 0.1105 & & & 0.1197 & \\
\hline
\end{tabular}

$\mathrm{N}=62, \mathrm{p}\langle 0.05, \mathrm{t}\rangle \pm 2, \alpha=0.05$

"FIG.2" includes regression results of all the 3 models. Behavioral literature has accentuated negative relationship between managerial overconfidence and dividend payout. However Pakistani managers are found to be less overconfident paying higher level of dividend out of their earning streams. This in turn rejects out hypothesis $\mathbf{H}_{\mathbf{1}}$ that in Pakistan managerial overconfidence decreases the dividend payout. Model 2 and Model 3 as explained by "FIG.2" thereby proves an insignificant $p$ value and t stat for overconfidence in effect to dividend per share. Other proposed hypothesizes suggest that moderating variables i.e individual, organizational, environmental of managerial discretion along with state ownership and political appointment strengthen the relationship between managerial overconfidence and dividend payout. All three models strongly support the moderating effects of CEO duality and firm size on the relationship between managerial overconfidence and dividend payout other than variables related to environmental level of managerial discretion, state ownership and political appointment. This proves our stated hypothesis $\mathbf{H}_{2}$ and $\mathbf{H}_{3}$ that in Pakistan, relationship between managerial overconfidence and dividend distribution is strengthened by CEO duality and firm size. The P- value and t- stat for the respective variables is up to the benchmark to support its significance.

Based on F-value for overall model significance, model 1 and model $2 \mathrm{~F}$ values are less than $\alpha(0.05)$, however model 3 is insignificant as its $f$ value is greater than the level of significance. This means that the interaction of moderating variable with independent variable has reduced the overall significance of model. $\mathrm{R}^{2}$ analysis advocates only $11 \%$ contribution of variation by the entire independent, moderating and controlling variables in the dividend payout by the Pakistani managers.

Thus regression analysis of Pakistani emerging market endures only the logical submission of negative relationship between managerial overconfidence and dividend distribution due to duality and firm size. All of the other hypothesis as per Pakistani markets are rejected and negates the literature apprehension.

\section{Discussion}

Various researches in the area of managerial behavior has proved the top management can potentially affect a firm's performance and its strategies [104; 82]. Overconfident managers take some sort of risky decisions as compared to their peer groups, in a variety of corporate spheres [6]. Out of the three main financial decision that senior management has to regard, dividend policy is the most imperative to boost the financial performance of company [6]. This research has been undertaken to investigate the managerial influence on dividend policy in terms of his overconfidence, in an emerging market of Pakistan. It has been observed that the 
behavioral aspects of managers' persuade their decision while formulating the dividend policy not only in developed market but also in an emerging market.

A recent research conducted in China on managerial overconfidence and dividend payout has provided sufficient ground for the relationship between the two [82]. But, our research is in contradiction with what has been proved significant in other emerging markets. Pakistani managers are not found to be painting the rosy picture of their cashflows, and share much of the income with the shareholders in the form of dividends.

Weak positive relationship between managerial overconfidence and dividend payout has been found which assert Pakistani managers are not prone to overconfidence while formulating dividend policy. The economic outlook of the Pakistan is bleak and uncertain, which explains why Pakistani managers are not buoyant about the future cash flows of their companies and prefer paying dividend. Also most of the firms are operating in losses which persuade managers to pay dividends.

We have also considered managerial discretion as a moderating variable to investigate if its effect strengthen or weakens the relationship between managerial overconfidence and dividend policy. Hambrick and Finkelstein [75], have commenced managerial discretion as a mode by which executives have great impact on company's performance in a developed market but evidence of it are hard to find in an emerging market [102]. According to the annual reports of Security and Exchange commission of Pakistan, almost 35\% companies registered on the stock exchange pay dividends. There is an intense pressure on the firm by its shareholders to pay dividend as they have a right to complain SECP if the dividends are not paid [105]. Such strains on a manager seem to be reducing his discretion while designing and implementing the dividend payout policy.

In Pakistani market, we have found that specifically at individual level CEO duality strengthens the negative relationship between the managerial overconfidence and dividend payout. CEO when also acting as a chairman of the board concerns more about the firm outlook and his own image. Dual positions offers more discretion to CEO which in turn allows him to pay fewer dividends as dividend payout can potentially harm the firm future outlook and his image as a commendable opportunist. So executives holding the dual positions in Pakistan pay fewer dividends and save more for the future to invest. Similar studies conducted in other developed countries also support the fact that if both positions are combined anyway, the balance can only be maintained by the enough intervention of independent directors from outside the firm [106]. So, it is better that CEO stick himself to the firm's business operations, while keeping the board chair aside.

Also the organizational level i.e. financial resource or cash availability attributes more discretion and power to the executives [107]. Greater the cash available to the executives less will be the dividend paid. Executives will reserve the portion of titanic cash flow for better future returns to augment the future outlook of the company. There is always a concealed intent of executives behind paying fewer dividends and reserving cash i.e. affirmative future outlook grants executives with more power and lucrative compensations. Secondly, holding onto cash allows a manger an increased control over the firm's assets and helps him gaining discretionary power over the firm's key investment decisions. As the firm's cash position improves, there is much less pressure of ultra-performance on a manager. Hence, they tend to invest in the projects that are in their own interests, bypassing the benefits of shareholders [108]. Countries where shareholder protection is weak, factors of retaining cash are not that important for the managers. In such a scenario, shareholders cannot force managers to pour out from extra cash [109].

Also we proposed that growth, political appointment and state ownership strengthens the relationship between dividend distribution and managerial overconfidence, however no statistical evidence was found to support the proposition in an emerging market.

In conclusion our research complies with the previous researches regarding managerial discretion at individual and organizational level. CEO duality and organizational resources can grant executives more leverage and discretion to formulate the financial and corporate decisions. Whether the company is located in developed or emerging market, managerial overconfidence comes in effect with managerial discretion and results in abridged dividend distribution.

\section{Limitation}

The following study is not without any precincts and shortcomings. First sample taken was exceedingly small due to non-availability of financial data. Secondly research is conducted on an emerging market of Pakistan, which restricts the generalization of our findings on other markets. Scholars are called to explore other countries emerging markets to find a substantial and generalized theory. Thirdly we have assumed only four variables of managerial discretion to unearth its effects on dividend distribution.

\section{Recommendation}

Literature suggests different techniques to tackle the overriding effect of managerial overconfidence and discretion on firm's decision.

- One way is the self-assessment of one's basic belief and their evaluation with the help of peers. 
- Once the faults are highlighted due to the individual causes, scenario analysis helps to remove the bottle necks. Scenarios are the highlighted details depicting how the future will unfold.

- Tailor made overconfidence quizzes help the manager to device the solution to their own behavioral issues and related problems. These quizzes offer awareness to the managers that helps contemplate whether to go for retention or dividend payout.

\section{Conclusion}

This study explores the empirical relationship between managerial overconfidence and dividend payout policy in Pakistani context. There is also a test conducted to find the moderating effect of managerial discretion with the above mentioned proposed independent and dependent variables respectively. The results were interesting and quite dissimilar from the other few researches conducted in emerging market scenarios. Weak positive relationship has been found to exist between overconfidence and dividend payout as oppose to literature that propose the negative relationship between the two. This substantiate that Pakistani managers are not prone to behavioral bias of overconfidence and pay enough dividend out of firm's income stream.

Out of all the moderating variables only CEO duality and firm size supports the proposed postulate. These two factors are found to strengthen the proposed relationship between managerial overconfidence and dividend payout in both the emerging markets and developed markets. Executives holding management and board positions at a time along with laudable firm size are found to augment the overconfidence among the managers which ultimately results in condense dividend payout. Only with the help of independent nonexecutive board of directors, balance can be maintained between the two positions of CEO and board chair. However there is no concept of independent non-executive board of directors in Pakistan [88].

This research also answer the calls of different researchers to investigate managerial biases in emerging market of underdeveloped countries. Scholars of Pakistan are invited to give this phenomenon a comprehensive investigation.

\section{Acknowledgment}

We, RABIA RASHEED and SEHRISH SADAQAT would like to express our gratitude to all those who gave us the possibility to complete this report.

All praises to Almighty Allah, The Light of Heavens and Earths, The One Who put good thoughts in one's mind, turn them into determinations and then makes the way towards their fulfillments showering all His Blessings throughout the journey. Best of the praises and Peace be upon all the Sacred Messengers and especially for the Last of them Hazrat Muhammad (SAWW) who are the minarets of knowledge for all the mankind.

We are deeply indebted to our supervisor Prof. SUMMAIYA CHUGTAI whose help, stimulating suggestions, knowledge, experience and encouragement helped us in all the times of study and analysis of the project in the pre and post research period.

Finally, an honorable mention goes to our parents Mr \& Mrs Rasheed and Mr \& Mrs Sadaqat for their understandings, love, encouragement and supports on us in completing this project.

\section{Reference}

[1] Black F (1976) The Dividend Puzzle, Journal of Portfolio Management, 2:5-84

[2] Brealey R, Myers SC (2003) Principles of Corporate Finance, 7th edition, New York: McGraw-Hill.

[3] Brealey R, Myers SC (1996) Principles of Corporate Finance, 5th edition, New York: McGraw-Hill.

[4] Ariely D (2008) Predictably Irrational: The Hidden Forces That Shape Our Decisions, Harper Collins.

[5] Simon, H. (1978) Rationality as Process and as Product of Thought, American Economic Review, 68(2):1-16.

[6] Ben-David I (2010) Behavioral Corporate Finance, Hamilton.

[7] Miller MH, Modigliani F (1961) Dividend Policy, Growth and the Valuation of Shares, Journal of Business, 34:411-433.

[8] Abor J, Bokpin GA (2010) Investment Opportunities, Corporate Finance and Dividend Payout Policy, Studies in Economics and Finance, 27:180-194

[9] Chen J, Dhiensiri N (2009) Determinants of Dividend Policy: The Evidence from New Zealand, International Research Journal of Finance and Economics, 34:18-28.

[10] Manos R (2002) Dividend Policy and Agency Theory: Evidence on Indian Firms, Working Paper, Institute for Development Policy and Management, University of Manchester.

[11] Easterbrook F (1984) Two Agency Cost Explanations of Dividends, American Economic Review, 74:650-659.

[12] Fama EF, Jensen MC (1983) Separation of Ownership and Control, Journal of Law and Economy, 88:288-307.

[13] Bhattacharya S (1979) Imperfect Information, Dividend Policy, and the 'Bird in the Hand' Fallacy, Bell Journal of Economics, 10:259-270.

[14] Miller MH, Rock K (1985) Dividend Policy under Asymmetric Information', Journal of Finance 40:1031-1051.

[15] John K, Williams J (1985) Dividends, Dilution and Taxes: A Signalling Equilibrium, Journal of Finance, 40:1053-1070.

[16] Lintner J (1956) Distribution of Incomes of Corporations among Dividends, Retained Earnings and Taxes, American Economic Review, 46:97-113.

[17] Fama EF, Babiak H (1968) Dividend Policy: An Emperical Analysis, Journal of American Statistical Association63:1132-1161

[18] Baker HK, Farrelly GE, Edelman RB (1985) A Survey of Management Views on Dividend Policy, Financial Management, 14:7884. 
[19] Pruitt SW, Gitman LJ (1991) The Interactions Between the Investment, Financing, and Dividend Decisions of Major US Firms, Financial Review, 26:409-430.

[20] Baker HK (1999) Dividend Policy Issues in Regulated and Unregulated Firms: A Managerial Perspective, Managerial Finance, 25:1-20.

[21] Brennan M (1970) Tax Reform and the Stock Market: An Asset Price Approach, American Economic Review, 23:417-427.

[22] Stapleton R (1972) Taxes, the Cost of Capital and the Theory of Investment Value, Economic Journal, 82:1273- 1292.

[23] Litzenberger RH, Ramaswamy K (1982) The Effects of Dividends on Common Stock Prices: Tax Effects or Information Effects, Journal of Finance, 37:429-443.

[24] Black F, Scholes MS (1974) The Effects of Dividend Yield and Dividend Policy on Common Stock Prices and Returns, Journal of Financial Economics, 1:1-22.

[25] Miller, M, Scholes MS (1982) Dividends and Taxes: Some Empirical Evidence, Journal of Political Economy, 90:1118-1141

[26] Allen F, Bernardo AE, Welch I (2000) A Theory of Dividends Based on Tax Clienteles, Journal of Finance, 55:2499-2536.

[27] Dhaliwal DS, Erickson M, Trezevant R (1999) A Test of the Theory of Tax Clienteles for Dividend Policies, National Tax Journal, 52:179-194.

[28] Seida JA (2001) Evidence of Tax-Clientele-Related Trading Following Dividend Increases, Journal of the American Taxation Association, 23:1-21.

[29] Smith C Jr., Watts RL (1992) The Investment Opportunity Set and Corporate Financing, Dividend and Compensation Policies, Journal of Financial Economics, 32:263-292.

[30] Fama F, French R (2001) Disappearing Dividends: Changing Firm Characteristics or Lower Propensity to Pay?, Journal of Financial Economics, 60:3-43.f

[31] Deshmukh S, Goel AM, and Howe KM (2009) CEO Overconfidence and Dividend Policy: Theory and evidence. Working paper, DePaul University

[32] Likitratcharoen D (2011) CEO Reputation and Dividend Payouts, International Proceedings of Economics Development and Research, 22:97-101

[33] Gaver JJ, Gaver KM (1993) Additional Evidence on the Association between the Investment Opportunity Set and Corporate Financing, Dividend and Compensation Policies, Journal of Accounting and Economics, 16:125-160.

[34] Abbott LJ (2001) Financing, Dividend and Compensation Policies Subsequent to a Shift in the Investment Opportunity Set, Managerial Finance, 27:31-48.

[35] Venkatesh PC (1989) The Impact of Dividend Initiation on the Information Content of Earnings Announcements and Returns Volatility, Journal of Business, 62:175-197.

[36] Fink, J., et al. (2006) Firm Age and Fluctuations in Idiosyncratic Risk, Working Paper, James Madison University and Rice University.

[37] Lintner J (1956) Distribution of Incomes of Corporations Among Dividends, Retained Earnings and Taxes, American Economic Review, 46:97-113.

[38] Brav A., et al. (2005) Payout Policy in the 21st Century, Journal of Financial Economics, 77:483-527.

[39] Hoberg G, Prabhala R (2009) Disappearing Dividends, Catering, and Risk, Review of Financial Studies, 22:79-116.

[40] Bhattacharya N (2003) Good Managers Work More and Pay Less Dividends, http://papers.ssrn.com/author=115728.

[41] Bhattacharyya N, Mawani A, Morrill C (2008) Dividend Payout and Executive Compensation: Theory and Evidence, Accounting and Finance, 48:521-541

[42] Easterbrook F (1984) Two Agency Cost Explanations of Dividends, American Economic Review 74:650-659.

[43] Jensen MC (1986) Agency Costs of Free Cash Flow, Corporate Finance and Takeovers, American Economic Review, 76:323-339.

[44] DeAngelo H, DeAngelo L, Stulz R (2006) Dividend Policy and the Earned/Contributed Capital Mix: A Test of the Life-Cycle Theory, Journal of Financial Economics, 81:227-254.

[45] Hammond JS, Keeney RL, Raiffa H (2006) The Hidden Traps in Decision Making, Harvard Business Review, 84:118-126.

[46] Svenson O (1981) Are We All Less Risky and More Skillful than Our Fellow Drivers?, Acta Psychologica, 47:143-148.

[47] Lichtenstein, S, Fischhoff B, Phillips LD (1982) Calibration of Probabilities: The State of the Art to 1980. In D. Kahneman, P. Slovic, and A. Tversky (Eds.), Judgement under Uncertainty: Heuristics and Biases, 306-334. New York: Cambridge University Press.

[48] Russo JE, Schoemaker PJH (1992) Managing Overconfidence, Sloan Management, 33:7-17.

[49] Soll JB (1996) Determinants of Overconfidence and Miscalibration: The Roles of Random Error and Ecological Structure, Organizational Behavior and Human Decision Processes, 65:117-137.

[50] Larwood L, Whittaker W (1977) Managerial Myopia: Self-Serving Biases in Organizational Planning, Journal of Applied Psychology, 62:194-198.

[51] Alicke M (1985) Global Self-Evaluation as Determined by the Desirability and Controllability of Trait Adjectives, Journal of Personality and Social Psychology, 49:1621-1630.

[52] Miller DT, Ross M (1975) Self-Serving Biases in the Attribution Of Causality: Fact or Fiction?, Psychological Bulletin, 82:213225 .

[53] Camerer C, Lovallo D (1999) Overconfidence and Excess Entry: An Experimental Approach, American Economic Review.

[54] Shane S, Stuart T (2002) Organizational Endowments and the Performance of University Start-Ups, Management Science, 48:154170.

[55] Kahnemann D, Lovallo D (1993) Timid Choices and Bold Forecasts: A Cognitive Perspective on Risk Taking, Management Science, 1:17-32.

[56] March JG, Shapira Z (1987) Managerial Perspectives on Risk and Risk Taking, Management Science, 33:1404-1418.

[57] Sitkin S, Pablo A (1992) Re-conceptualizing the Determinants of Risk Behavior, Academy of Management Review, 17:9-39.

[58] Kidd JB (1970) The Utilization of Subjective Probabilities in Production Planning, Acta Psychologica, 34, 338-347

[59] Moore PG (1977) The Manager's Struggle with Uncertainty, Journal of the Royal Statistical Society Series A, 149:129-165.

[60] Knowledge@Warton, 2008.

[61] Charan R, Useem J, Harrington A (2002) Why Companies Fail, Fortune, 145:50-64.

[62] Sanders WG, Hambrick D (2007) Swinging for the Effects: The Effects of CEO Stock Options on Company Risk Taking and Performance, Academy of Management Journal, 50:1055-1078.

[63] Hayward M (2007) Ego Check: Why Executive Hubris is Wrecking Companies and Careers and How to Avoid the Trap, New York: Kaplan Business

[64] Langer, E. (1975) 'The Illusion of Control', Journal of Personality and Social Psychology, 32:311-328.

[65] Heaton, J. B. (2002) 'Managerial Optimism and Corporate Finance', Financial Management, 31:33-45. 
[66] Hackbarth D (2004) 'Determinants of Corporate Borrowing: A Behavioral Perspective', Working Paper.

[67] Landier A, Thesmar D (2006) Contracting with Optimistic Entrepreneurs: Theory and Evidence, Review of Financial Studies, Forthcoming.

[68] Cordeiro L (2009) Managerial Overconfidence and Dividend Policy, Working Paper, London Business School.

[69] Ben-David I, Graham JR Harvey CR (2009) Managerial Overconfidence and Corporate Policies, Working Paper, Duke University and Ohio State University.

[70] Trevelyan R (2008) Optimism, Overconfidence and Entrepreneurial Activity, Management Decision, 46:986-1001.

[71] Finkelstein S, Hambrick D (1990) 'Top Management Team Tenure and Organizational Outcomes: The Moderating Role of Managerial Discretion', Administrative Science Quarterly, 35:484-503.

[72] Gervais S, Heaton JB, Odean T (2005) Overconfidence, Investment Policy and Manager Welfare, Working Paper.

[73] Hambrick D (2007) Upper Echelons Theory: An update, Academy of Management Review, 32:334-343.

[74] Finkelstein S, Boyd B (1998) How Much Does the CEO Matter? The Role of Managerial Discretion in the Setting of CEO Compensation, Academy of Management Journal, 41:179-199.

[75] Hambrick D, Finkelstein S (1987) 'Managerial Discretion: A Bridge Between Polar Views of Organizational Outcomes. In B. Staw and L. Cummings (Eds.)', Research in Organizational Behavior, 9:369-406.

[76] Child J (1972) Organizational Structure, Environment, and Performance: The Role of Strategic Choice, Sociology, 6:1-22.

[77] Jensen MC (1986) Agency Costs of Free Cash Flow, Corporate Finance and Takeovers, American Economic Review, 76:323-339.

[78] Stulz R (1990) Managerial Discretion and Optimal Financing Policy, Journal of Financial Economics, 26:3-27.

[79] Scordis NA, Pritchett ST (1998) Policyholder Dividend Policy and the Costs of Managerial Discretion, Journal of Risk and Insurance, 65:319-330.

[80] DeAngelo H and DeAngelo L (2006), The Irrelevance of the MM Dividend Irrelevance Theorem, Journal of Financial Economics, 79, 293-315.

[81] Brav A., et al. (2004) 'Payout Policy in the 21 st Century', NBER Working Paper, No. 9657.

[82] Chen S, Zheng H, Wu S (2011) 'Senior Manager Overconfidence, Managerial Discretion and Dividend Policy: A Study of Chinese Listed Companies’, African Journal of Business Management, 5:12641-12652.

[83] Carpenter MA, Golden BR (1997) Perceived Managerial Discretion: A Study of Cause and Effect, Strategic Managerial Journal, 18:187-206.

[84] Jensen M, Meckling W (1976) Theory of the Firm: Managerial Behavior, Agency Costs and Capital Structure, Journal of Financial Economics, 3:305-60.

[85] Morck, R, Shleifer A, Vishny RW (1988) Management Ownership and Market Valuation: An Empirical Analysis, Journal of Financial Economics, 20:293-315.

[86] Myers S (1977) Determinants of Corporate Borrowing, Journal of Financial Economics, 5:147-75.

[87] Gomes ML, Nunez MN, Guttierrez I (2001) The Role of Family Ties in Agency Contracts, Academy of Management Journal, 44:81-95.

[88] ALI SHAH, SYED ZULFIQAR (2009) Corporate Governance and Financial Performance : A Comparative Study of Developing and Developed Markets. PhD thesis, Mohammad Ali Jinnah University, Karachi.

[89] Rechner PL, Dalton DR (1991) 'CEO Duality and Organizational Performance: A Longitudinal Analysis, Strategic Management Journal, 12:155-161.

[90] Jensen MC (1993) The Modern Industrial Revolution, Exit, and the Failure of Internal Control Systems, Journal of Finance, 48:831-880.

[91] Finkelstein S, D’Aveni R (1994) CEO Duality as a Double-Edged Sword: How Boards of Directors Balance Entrenchment Avoidance and Unity of Command, Academy of Management Journal, 37:1079-1108.

[92] Kesner IF, Victor B, Lamont B (1986) Board Composition and the Commission of Illegal Acts: An Investigation of Fortune 500 Companies, Academy of Management Journal, 29:789-799.

[93] Hambrick D, Finkelstein S (1995) The Effects of Ownership Structure on Conditions at the Top: The Case of CEO Pay Raises, Strategic Management Journal, 16:175-194.

[94] Hall R (1992) The Strategic Analysis of Intangible Resource, Strategic Management Journal, 13:135-144.

[95] Penrose, E. T. (1959) The Theory of the Growth of the Firm, Wiley: New York. Perspective on Risk Taking, Management Science, $1: 17-32$.

[96] Boyd BK, Gove S (2006) Managerial Constraint: The Intersection Between Organizational Task Environment and Discretion. In J. David J. Ketchen and D. D. Bergh. (Eds.), Research Methodology in Strategy and Management, 3:57-95.

[97] March HG, Sivion HA (1958) Organization, Wiley: New York

[98] Cyert RM, March JG (1963) A Behavioral Theory of the Firm, Prentice Hall, Englewood Cliffs, NJ.

[99] Boyd BK, Salamin A (2001) Strategic Reward Systems: A Contingency Model of Pay System Design, Strategic Management Journal, 22:777-792.

[100] Boyd BK, Gove S (2006) Managerial Constraint: The Intersection Between Organizational Task Environment and Discretion. In J. David J. Ketchen and D. D. Bergh. (Eds.), Research Methodology in Strategy and Management, 3:57-95.

[101] Dess GG, Beard DW (1984) Dimensions of Organizational Task Environment, Administrative Science Quarterly, 29:52-73.

[102] Li JT, Tang Y (2010) CEO Hubris and Firm Risk Taking in China: The Moderating Role of Managerial Discretion, Academy of Management Journal, 53:45-69.

[103] Lioukas S, Bourantas D, Papadakis V (1993) Managerial Autonomy of State-Owned Enterprises: Determining Factors, Organization Science, 4:645-655.

[104] Crossland C, Hambrick DC (2011) Differences in Managerial Discretion Across Countries: How Nation-Level Institutions Affect the Degree to which CEOs Matter, Strategic Management Journal, 32:797-819.

[105] Javid, A, Iqbal R (2010) Corporate Governance in Pakistan: Corporate Valuation,Ownership and Financing, PIDE Working Papers.

[106] Breeden, R. C, et al. (1993)The Fight for Good Governance, Harvard Business Review January February, 76-83.

[107] 07.Scarborough NM, Zimmerer TW (2006) Effective Small Business Management: An Entrepreneurial Approach (8th Ed.), Upper Saddle River, NJ: Pearson Prentice Hall.

[108] Jensen MC (1986) Agency Costs of Free Cash Flow, Corporate Finance and Takeovers, American Economic Review, 76:323-339.

[109] Dittmar, A., S. J. Mahrt, and H. Sarvaes. (2003) 'International Corporate Governance and Corporate Cash Holdings', Journal of Financial and Quantitative Analysis, 28, 111-133. 